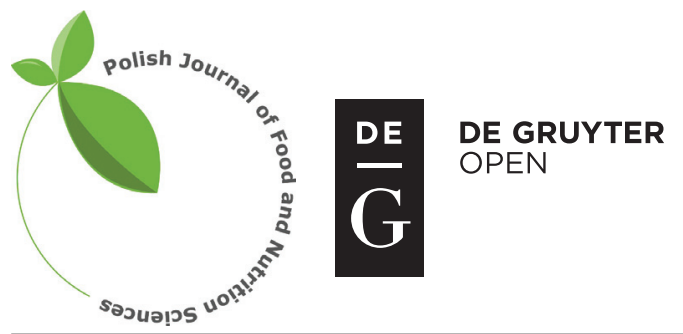

Pol. J. Food Nutr. Sci., 2018, Vol. 68, No. 4, pp. 335-345

DOI: $10.2478 /$ pjfns-2018-0005 http://journal.pan.olsztyn.pl

Original research article

Section: Food Quality and Functionality

\title{
Effect of Dietary Fibre Fractions on In Vitro Digestibility of Rapeseed Napin Proteins
}

\author{
Marcel Skejovic Joehnke, Susanne Sørensen, Charlotte Bjergegaard, \\ Keld Ejdrup Markedal, Jens Christian Sørensen* \\ Department of Food Science, Faculty of Science, University of Copenhagen, \\ Rolighedsvej 30, DK-1958 Frederiksberg C, Denmark
}

Key words: in vitro protein digestibility, total dietary fibre, rapeseed napin proteins, plant food ingredients

Protein digestibility may be influenced by the presence of dietary fibre affecting the nutritional quality of a feed or food product. This study investigated the interplay between rapeseed (Brassica napus L.) protein and fibre constituents separated by industrially scalable pilot plant processing and recombined in mixed samples. Total dietary fibre (TDF) fractions were isolated from rapeseed hulls (TDF-RH) and purified rapeseed embryo fibres (TDF-RE). The effect of TDF sources on in vitro protein digestibility (IVPD) of a rapeseed protein concentrate rich in napin proteins (RP2) was assessed at three inclusion levels $(200,333$, and $500 \mathrm{mg} / \mathrm{g}$ DM) using a sequential transient proteolysis by pepsin $(1 \mathrm{~h})$ and pancreatin $(1 \mathrm{~h})$. The IVPD of RP2 was dose-dependently decreased upon addition of hull fibres at all inclusion levels $(8.9-26.6 \% ; P<0.05)$, whereas the effect of embryo fibres was of a markedly lower magnitude and only significant at the medium to high levels $(7.3-8.9 \% ; P<0.05)$. These results demonstrated that TDF fractions obtained from rapeseed differentially affect the protein digestibility of rapeseed napin proteins depending on the fibre source and inclusion level.

\section{ABBREVIATIONS}

BV, biological value; DF, dietary fibre; DH, degree of hydrolysis; DM, dry matter; E:S ratio, enzyme to substrate ratio; IDF, insoluble dietary fibre; IVPD, in vitro protein digestibility; IVPD PT, overall protein digestibility; NSP, non-starch polysaccharides; $\mathrm{PD}$, protein digestibility; RE, rapeseed embryo fibres; $\mathrm{RH}$, rapeseed hulls; $\mathrm{RP}(2)$, rapeseed protein concentrate (2) rich in napin proteins; SDF, soluble dietary fibre; TD, true protein digestibility; TDF, total dietary fibre; TDF-RE, total dietary fibre isolated from rapeseed embryo fibres; TDF-RH, total dietary fibre isolated from rapeseed hulls; TNBS, trinitrobenzenesulfonic acid; U-samples, untreated samples; UPT-samples, uncorrected overall protein digestibility samples.

\section{INTRODUCTION}

Rapeseed (B. napus L.) is the second most abundant oilseed in the world, exceeded only by soybean species, and it is widely used for the production of high quality edible oils [USDA FAS, 2018]. The residual rapeseed meal or press cake, currently considered as byproducts of the rapeseed oil extraction process, are consequently abundantly available.

\footnotetext{
* Corresponding Author: Tel.: +45 35332435

E-mail: jchs@food.ku.dk (J.C. Sørensen)

Other email addresses: marcel@food.ku.dk (M.S. Joehnke), sus@food.ku.dk (S. Sørensen), cbj@food.ku.dk (C. Bjergegaard), kea@food.ku.dk (K.E. Markedal).
}

The meal is presently restricted to utilization mainly as a protein source in animal feeding [Campbell et al., 2016]. However, the high protein content and well-balanced amino acid composition of the meal support its potential to serve as an alternative source of plant protein for human consumption [Wanasundara, 2011]. Human studies have indeed demonstrated a high nutritional quality of isolated rapeseed protein, comparable to animal sources such as milk and egg proteins, and ranking above several other plant proteins [Bos et al., 2007; Fleddermann et al., 2013].

The application of rapeseed for preparation of protein-rich food ingredients has been limited due to the presence of antinutritional compounds and its high fibre content [Khajali \& Slominski, 2012]. The seeds of black-seeded B. napus L. rape contain about $460 \mathrm{mg} / \mathrm{g}$ fat, $50 \mathrm{mg} / \mathrm{g}$ sucrose, $10 \mathrm{mg} / \mathrm{g}$ oligosaccharides, $180 \mathrm{mg} / \mathrm{g}$ total dietary fibre (TDF), $200 \mathrm{mg} / \mathrm{g}$ protein, and $40 \mathrm{mg} / \mathrm{g}$ ash [Kracht et al., 2004; Slominski et al., 2012]. TDF encompasses the sum of water-insoluble dietary fibre (IDF) and soluble dietary fibre (SDF) [AOAC International, 1985]. The major fibre type in seeds of rape, IDF, is primarily found in the rapeseed hull fraction and consequently exerts the greatest effect on food and feed [Bjergegaard et al., 1991a]. IDF in rapeseed consists of lignins and celluloses, usually along with some hemicelluloses, whereas SDF mainly consists of pectins, hemicelluloses, mixed $\beta$-glucans, gums, and mucilages [Asp et al., 1983; Bjergegaard et al., 1991a]. In addition, a broad group of indigestible compounds are found in close association with DF, such as cell wall proteins (e.g. glycoproteins), phenolic acid derivatives, oligosaccha- 
rides of the raffinose family, and tannins [Bjergegaard et al., 1997]

Dietary fibres (DF) have been associated with a wide range of potential human health benefits, including a lowering of the risk of cardiometabolic and cardiovascular diseases [Grundy et al., 2016]. However, potential interactions of specific DF components with other food matrix components, such as rapeseed proteins, may lead to drastic changes in protein functionality and digestibility [Zhang et al., 2017]. Furthermore, the formation of complexes between rapeseed proteins and polysaccharides may elicit major shifts in the physicochemical properties [Stone et al., 2014]. The physiological and antinutritional effects of isolated SDF and IDF fractions from rapeseeds, rapeseed meals, and rapeseed hulls added to a basal casein diet have been evaluated in rats [Bjergegaard et al., 1991a, b]. These trials demonstrated that DF from nearly all sources and at all levels have a marked negative effect on the biological value (BV) and true protein digestibility (TD) of casein. Subsequently, a study in rats showed that addition of IDF isolated from seeds of rape to the basal casein diet led to a decreased TD, and to a lesser extent BV, whereas SDF did not influence the TD and evidently decreased the BV [Ochodzki et al., 1995]. In addition to the major DF fractions, purified DF components such as cellulose, pectin, lignin, guar gum added to a basal corn starch-based casein diet have been reported to dose-dependently affect the protein utilization in rats, partly attributable to an increased endogenous faecal nitrogen excretion [Shah et al., 1982]. The multifaceted interactions of DF with other nutritional components, potentially affecting digestibility and thereby the nutritional value, warrant further research into this field. The effects of DF on proteins within a food matrix are particularly relevant due to the emerging trend towards an increased inclusion of plant-derived ingredients in human nutrition [Richter et al., 2015].

To supplement existing knowledge from studies in living organisms, in vitro studies may play a role due to their simplicity and cost-efficiency. Studies in vitro have demonstrated inhibitory effects of DF on proteolytic enzyme activity, exerted through a variety of different mechanisms, such as physical non-specific adsorption of enzymes onto fibre surfaces or absorption of enzymes into the fibre matrix [Dutta \& Hlasko, 1985; Hansen, 1986]. The influence of DF on in vitro protein digestibility (IVPD) has previously been investigated using only a limited number of specific intact protein substrates, e.g. milk proteins such as caseins [Acton et al., 1982; Gagne \& Acton, 1983]. Lignin and pectin was reported in these studies to substantially reduce the IVPD of casein protein, whereas holocellulose containing cellulose and some hemicelluloses only had a minor effect. Hence, studies covering the effects of DF on digestibility of various alternative protein types are currently lacking. Furthermore, the direct influence of DF isolated from e.g. rapeseed on digestibility of napin proteins originating from the same source has hitherto not been investigated.

For the last decades, many processing methods have been developed for purification of food-grade protein from rapeseed, as reviewed elsewhere [Tan et al., 2011]. However, only few have been commercially viable due to low protein recov- ery, high processing costs, and poor product quality. The processing of rapeseed generally has a major effect on the level of antinutritional factors and nutritive value of the derived products [Mansour et al., 1993]. Minimal processing may be a part of the solution due to potential benefits on the organoleptic and nutritional quality [Pasha et al., 2014]. In addition, processing to a minimal degree is advantageous as it increases the sustainability and affordability of the food production. Novel processing methods are needed to exploit the full potential of rapeseed, and pilot-scale studies are particularly valuable in this connection due to their scalability to industrial production and preparation of larger product quantities.

In the present study, total dietary fibre (TDF) fractions were isolated from rapeseed hulls (yielding TDF-RH) and rapeseed embryo fibres (yielding TDF-RE). The purpose of the work was to investigate the effect of TDF fractions from the same source added at different inclusion levels (low, $200 \mathrm{mg} / \mathrm{g}$; medium, $333 \mathrm{mg} / \mathrm{g}$; high, $500 \mathrm{mg} / \mathrm{g}$ of total DM) on IVPD of a rapeseed protein concentrate (RP2) rich in $2 S$ napin proteins. IVPD was determined using a novel combination of assay methods applicable for testing the effects of various food constituents on protein digestibility. Fibre addition to feed is a standard procedure in animal nutrition and therefore it is important to determine the potential effects of specific fibre fractions on protein digestibility in relation to human nutrition. To the authors' best knowledge, this is the first study to report a direct effect of TDF on digestibility of protein from rapeseed under in vitro experimental conditions.

\section{MATERIALS AND METHODS}

\section{Chemicals and reagents}

All chemicals of analytical grade were supplied by Sigma-Aldrich Corporation (St. Louis, MO, USA) besides the specified exceptions. Absolute alcohol (99.9\% purity) was purchased from Kemetyl A/S (Køge, DK). Acetone was obtained from Bie \& Berntsen A/S (Rødovre, DK). Purified water obtained from a Milli-Q Plus system (Millipore Corporation, Milford, MA, USA) was used for buffer and reagent preparations. All experimental analysyes were performed in triplicates.

\section{Sample preparation}

The rapeseed protein concentrate (RP2) and total dietary fibre fractions used in this study were all prepared from black-seeded rapeseed (B. napus L., cv. Express) by an industrially scalable pilot plant processing presented in Figure 1. Rapeseed hulls (RH) produced by dry dehulling were obtained from Lehnsgaard Rapsolie A/S (Aakirkeby, DK). For extraction of rapeseed protein (RP2) and embryo fibres (RE) from rapeseed press cake, a mild aqueous acidic extraction method without use of organic solvents was applied according to Patent WO/2012/149941 [Andersen et al., 2012]. Brief$1 \mathrm{y}$, the rapeseed press cake was suspended under acidic conditions, homogenized, and separated into: (1) a water-soluble phase containing compounds such as proteins, carbohydrates, soluble fibres, glucosinolates, and phenolics and (2) a water-insoluble phase containing mainly proteins and insol- 


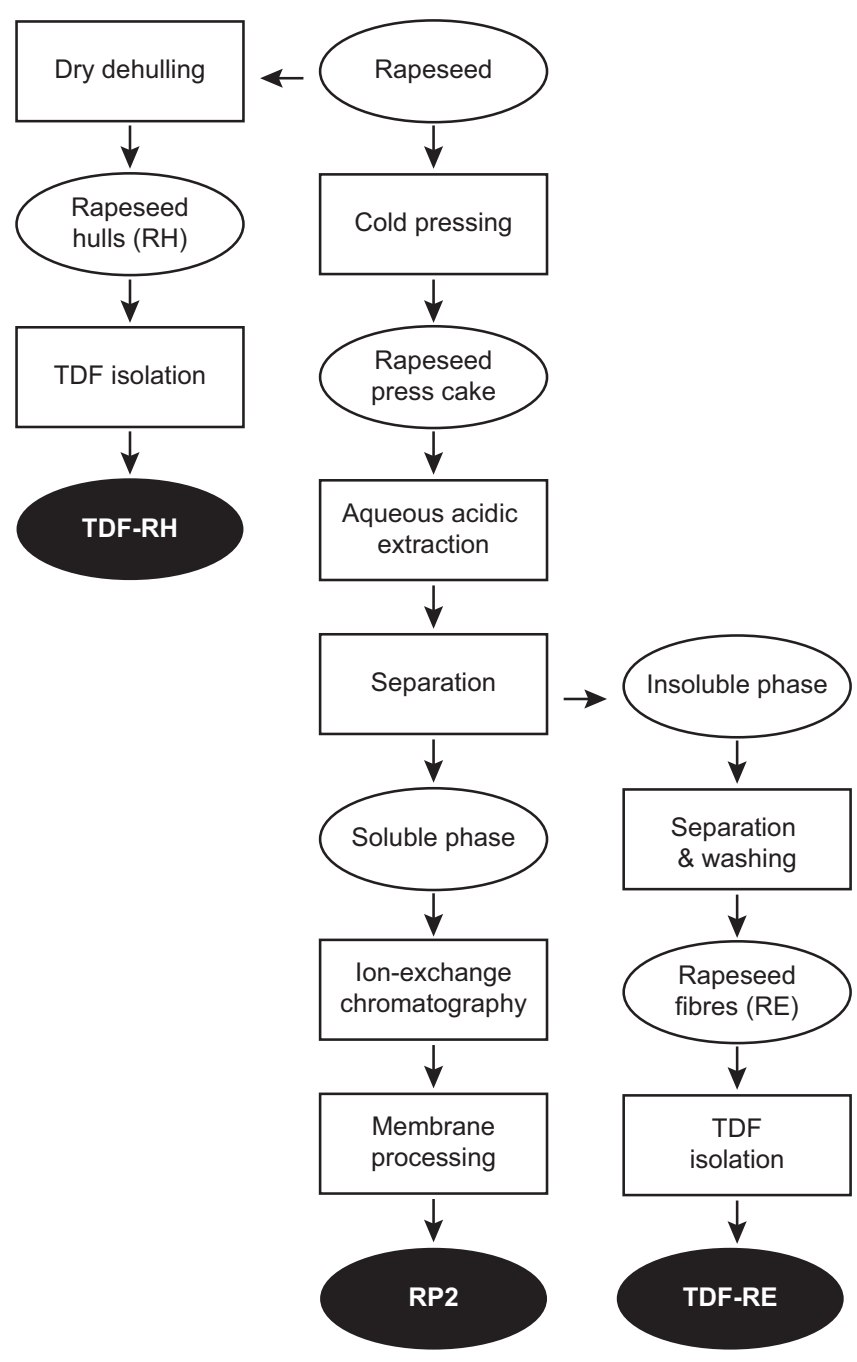

FIGURE 1. Schematic overview of the pilot plant extraction process of rapeseed (B. napus L., cv. Express).

Post-process defatting of all intermediate products was not a part of the pilot plant process and was performed subsequently in the laboratory. TDF isolation was performed on defatted rapeseed hulls $(\mathrm{RH})$ and purified rapeseed embryo fibres (RE). The black ellipses show the final rapeseed products investigated: total dietary fibre isolated from rapeseed hulls (TDF-RH), total dietary fibre isolated from purified rapeseed embryo fibres (TDF-RE), and rapeseed protein concentrate 2 rich in napin proteins (RP2).

uble fibres. The water-soluble phase containing a fraction rich in $2 S$ napin proteins (RP2) was isolated using ion-exchange chromatography. The water-insoluble phase was subjected to further washing steps with water to remove soluble components and obtain a purified water-insoluble fibre fraction rich in embryo fibres (RE). These two isolated rapeseed fractions were dried by spray-drying or freeze-drying, respectively, to obtain powder products, prior to post-process defatting as described below.

\section{Chemical analyses}

Post-process defatting of all intermediate rapeseed products was performed using an ASE $200^{\circledR}$ Accelerated Solvent Extractor system (DIONEX Corp., Sunnyvale, CA, USA) equipped with stainless steel extraction cells. For all experiments, cyclohexane was used as the solvent. The extraction cells were loaded with 1.5-8 g of milled powder samples. The extraction conditions were as follows: temperature, $80^{\circ} \mathrm{C}$; cartridge pressure, 1000 psi; three 5-minute static extraction cycles.

Dry matter (DM) content of defatted samples was determined gravimetrically according to AOAC Official Method 950.46 [AOAC International, 2000] using a HB43 Halogen Moisture Analyzer (Mettler Toledo, Columbus, OH, USA). The starting weight of samples was 0.5-5.0 g, depending on composition, and drying was performed using a quartz heater at $105^{\circ} \mathrm{C}$ until the variation of mass was less than $\pm 0.001 \mathrm{~g}$ over a period of $30 \mathrm{~s}$.

Protein content of defatted samples was analysed using an Elementar vario MACRO cube CHNS analyser (Elementar Analysensysteme $\mathrm{GmbH}$, Hanau, DE) with helium as carrier gas. The CHNS elemental analysis is based on the Dumas combustion method. The crude protein content based on dry matter was calculated from total nitrogen using a standard conversion factor of 6.25 .

\section{Total dietary fibre (TDF) isolation}

Total dietary fibre (TDF) isolation followed, with a few modifications, a previously described enzymatic gravimetric method [Asp et al., 1983; Bjergegaard et al., 1991a, 1997]. Defatted rapeseed hulls (RH) and rapeseed embryo fibres (RE) were milled in an analytical mill (IKA All basic; $I K A$-Werke GmbH, Staufen, Germany) and sieved at $300 \mu \mathrm{m}$. The samples were weighed into Erlenmeyer flasks and suspended in sodium phosphate buffer $(0.1 \mathrm{~mol} / \mathrm{L}, \mathrm{pH} 6.0)$ at approximately $50 \mathrm{~g} / \mathrm{L}$ concentration DM. The steps involving gelatinization and addition of the starch degrading enzyme Termamyl were omitted due to the minor quantity of starch in rapeseed [Ochodzki et al., 1995]. The $\mathrm{pH}$ was adjusted to 1.5 with $\mathrm{HCl}(1 \mathrm{~mol} / \mathrm{L})$ or $\mathrm{NaOH}(1 \mathrm{~mol} / \mathrm{L})$. Pepsin $(\mathrm{EC}$ 3.4.23.1, P7000, $920 \mathrm{U} / \mathrm{mg}$ protein, Pepsin from porcine gastric mucosa) was added at 1:5 enzyme to DM mass ratio and samples were incubated in a water bath (LSB Aqua Pro model; Grant Instruments, Cambridge, UK) shaking at $80 \mathrm{rpm}$ for $2 \mathrm{~h}$ at $40^{\circ} \mathrm{C}$. To increase the $\mathrm{pH}$, sodium phosphate buffer $(0.2 \mathrm{~mol} / \mathrm{L}, \mathrm{pH} 6.8)$ was added in a volume corresponding approximately to $2: 5$ volume ratio relative to the initial solubilization volume. The $\mathrm{pH}$ was adjusted to 6.8 with $\mathrm{HCl}$ $(1 \mathrm{~mol} / \mathrm{L})$ or $\mathrm{NaOH}(1 \mathrm{~mol} / \mathrm{L})$. Pancreatin $(4 \times \mathrm{USP}, \mathrm{P} 1750$, Pancreatin from porcine pancreas) was added at 1:5 enzyme to DM mass ratio and the samples were incubated in a water bath (LSB Aqua Pro model; Grant Instruments, Cambridge, UK) shaking at $80 \mathrm{rpm}$ for $2 \mathrm{~h}$ at $40^{\circ} \mathrm{C}$. After incubation, $\mathrm{pH}$ was adjusted to 4.5 with acetic acid $(0.94 \mathrm{~mol} / \mathrm{L})$ and $\mathrm{HCl}$ $(1 \mathrm{~mol} / \mathrm{L})$. The samples were cooled in an ice bath and transferred to centrifugal tubes (Thermo Fisher Scientific Inc., Waltham, MA, USA). TDF isolation was performed with cold $999 \mathrm{~mL} / \mathrm{L}$ absolute ethanol added to a final ethanol concentration exceeding $700 \mathrm{~mL} / \mathrm{L}$ and the suspensions were stored for a minimum of $4 \mathrm{~h}$ at $5^{\circ} \mathrm{C}$. The pellets containing TDF were obtained by centrifugation at $3400 \times g$ for $5 \mathrm{~min}$ (Varifuge 3.0; Heraeus Sepatech, Hanau, Germany) and supernatants were discarded. The pellets were sequentially washed with cold $780 \mathrm{~mL} / \mathrm{L}$ ethanol, cold absolute $999 \mathrm{~mL} / \mathrm{L}$ alcohol, and cold acetone with in-between centrifugations at $3400 \times g$ for $5 \mathrm{~min}$. 
Two TDF fractions isolated from rapeseed hulls (TDF-RH) and rapeseed embryo fibres (TDF-RE) were obtained after air drying. The TDF fractions were milled (IKA All basic; $I K A$-Werke GmbH, Staufen, Germany) prior to chemical analyses, using the previously described methods.

\section{In vitro protein digestibility (IVPD) procedure}

Simulated gastro-pancreatic digestion was performed, with a few modifications, according to a previously described static, multi-step IVPD method [Joehnke et al., 2018]. The composition of all samples and mixtures, and their relative proportions of DM and protein are presented in Table 1. TDF fractions were added in three different levels (low, $200 \mathrm{mg} / \mathrm{g} \mathrm{DM}$; medium, $333 \mathrm{mg} / \mathrm{g} \mathrm{DM}$; high, $500 \mathrm{mg} / \mathrm{g}$ DM) in sample mixtures containing a constant amount of RP2 product (approximately $72 \mathrm{mg} \mathrm{DM}$, corresponding to $50 \mathrm{mg}$ protein). Single constituent samples of RP2 and TDF fractions were also tested alone in equivalent quantities as found in the sample mixtures. Free alanine amino acids (Merck, Darmstadt, DE) functioning as standards and blanks containing only $0.05 \mathrm{M} \mathrm{HCl}$ were also included. The enzymatic assay consisted of sequential hydrolysis by pepsin $\left(1 \mathrm{~h}, 37^{\circ} \mathrm{C}\right)$ followed by pancreatin $\left(1 \mathrm{~h}, 37^{\circ} \mathrm{C}\right)$. The enzyme to substrate protein (E:S) ratios of all samples and mixtures according to the digestion steps are presented in Table 2. Besides mechanical shaking in a water bath $(80 \mathrm{rpm}$; LSB Aqua Pro model; Grant Instruments, Cambridge, UK), the samples were also mixed manually at $10 \mathrm{~min}$ intervals during the assay to ensure a proper solubilization of the powders.

IVPD (\%) of untreated samples (U-samples) and uncorrected overall protein digestibility samples (UPT-samples) obtained following hydrolysis by both pepsin and pancreatin was quantified using an trinitrobenzenesulfonic acid
(TNBS)-based assay method [Joehnke et al., 2018]. The results were expressed relative to an alanine standard solution representing $100 \%$ protein digestibility (PD) by calculating the ratio between the concentration of free $\alpha$-amino groups in the samples and the alanine standard. The starting level of hydrolysis in U-samples was subsequently subtracted from the UPT-samples to obtain corrected overall protein digestibility (IVPD PT \%) values. The calculation included a correction for the value of blank samples containing only buffer and enzymes, thus accounting for self-digestion of enzymes.

\section{Statistical analysis}

Statistical analysis was performed using GraphPad Prism 7 (GraphPad Software Inc., San Diego, CA, USA). The results are presented as mean \pm standard deviation. Statistically significant differences amongst multiple samples were determined by one-way analysis of variance (ANOVA) followed by Tukey's (sample vs. sample) or Dunnett's (sample vs. control) post hoc tests for pairwise multiple comparisons. Multiplicity adjusted $P$ values were calculated and differences were considered statistically significant at three levels: $P<0.05, P<0.01$, and $P<0.001$. Statistical differences between two samples was assessed by unpaired student's $t$ test and significance was considered at $P<0.05$, whereas ns denoted non-significant differences.

\section{RESULTS AND DISCUSSION}

\section{The composition of samples and mixtures}

The pilot plant process used to prepare the napin-rich rapeseed protein concentrate (RP2) and TDF fractions from rapeseed is illustrated in Figure 1. TDF fractions were iso-

TABLE 1. The composition of samples and mixtures. ${ }^{1}$

\begin{tabular}{|c|c|c|c|c|c|c|}
\hline \multirow{2}{*}{$\begin{array}{l}\text { Samples } \\
\text { and mixtures }\end{array}$} & \multicolumn{2}{|c|}{ Composition } & \multicolumn{4}{|c|}{ Relative proportion } \\
\hline & $\begin{array}{c}\mathrm{DM} \\
(\%)\end{array}$ & $\begin{array}{l}\text { Protein } \\
(\% \text { DM })\end{array}$ & $\begin{array}{c}\mathrm{RP} 2 \\
(\% \mathrm{DM}) \\
\end{array}$ & $\begin{array}{c}\text { TDF } \\
(\% \text { DM) }\end{array}$ & $\begin{array}{c}\mathrm{RP} 2 \\
\text { (\% protein) }\end{array}$ & $\begin{array}{c}\text { TDF } \\
\text { (\% protein) }\end{array}$ \\
\hline \multicolumn{7}{|c|}{ Samples } \\
\hline RP2 & $96.2 \pm 0.2$ & $69.5 \pm 0.3$ & 100 & 0 & 100 & 0 \\
\hline TDF-RH & $91.1 \pm 0.2$ & $12.6 \pm 0.0$ & 0 & 100 & 0 & 100 \\
\hline TDF-RE & $91.0 \pm 0.1$ & $6.0 \pm 0.1$ & 0 & 100 & 0 & 100 \\
\hline \multicolumn{7}{|c|}{ TDF-RH mixtures } \\
\hline Low & $95.1 \pm 0.1$ & $58.2 \pm 0.2$ & 80 & 20 & 95.7 & 4.3 \\
\hline Medium & $94.4 \pm 0.1$ & $50.6 \pm 0.2$ & 66.7 & 33.3 & 91.7 & 8.3 \\
\hline High & $93.5 \pm 0.1$ & $41.1 \pm 0.1$ & 50 & 50 & 84.7 & 15.3 \\
\hline \multicolumn{7}{|c|}{ TDF-RE mixtures } \\
\hline Low & $95.1 \pm 0.1$ & $56.8 \pm 0.2$ & 80 & 20 & 97.9 & 2.1 \\
\hline Medium & $94.4 \pm 0.1$ & $48.4 \pm 0.2$ & 66.7 & 33.3 & 95.8 & 4.2 \\
\hline High & $93.5 \pm 0.1$ & $37.8 \pm 0.2$ & 50 & 50 & 92.0 & 8.0 \\
\hline
\end{tabular}

${ }^{1}$ The values for RP2 and TDF fractions were determined experimentally, while the mixtures represent theoretically calculated values. Abbreviations used: rapeseed protein concentrate 2 rich in napin proteins (RP2), total dietary fibre isolated from rapeseed hulls (TDF-RH), total dietary fibre isolated from rapeseed embryo fibres (TDF-RE). Low, Medium, and High refers to the inclusion levels of TDF fractions in the mixtures. 
lated from rapeseed hulls (TDF-RH) and rapeseed embryo fibres (TDF-RE) using a gravimetric-enzymatic procedure [Asp et al., 1983; Bjergegaard et al., 1991a, 1997]. DF may be added to a diet either by substitution of one of the other dietary components in equivalent amount or by addition of fibre to the total diet (dilution) [Shah et al., 1982]. In this study, the TDF fractions were added to sample mixtures in realistic levels likely to induce a quantifiable effect on protein digestibility. The composition of samples and mixtures containing added total dietary fibre (TDF) fractions are presented in Table 1. The results showed that RP2 contained $69.5 \%$ protein based on DM, whilst the protein content of TDF-RH and TDF-RE fractions was $12.6 \%$ and $6.0 \%$, respectively. Hence, RP2 contained approximately $30 \%$ of the total $\mathrm{DM}$ as non-protein content, which in contrast to the isolated TDF fractions is dominated by SDF compared to IDF [Asp et al., 1983; Bjergegaard et al., 1991a]. Since the quantity of RP2 in all samples was kept constant with addition of higher levels of TDF fractions, the relative ratio of SDF to IDF was progressively lowered in the mixed samples. Therefore, the non-protein content of combined samples primarily consisted of TDF due to the defatting step prior to digestion (uncorrected for ash content), but the specific composition of TDF in relation to relative levels of SDF and IDF remains to be clarified in further studies.

The relative mass ratios of TDF to protein in black-seeded $B$. napus L. oilseed rape and its derived defatted meal can be estimated based on composition to be approximately 0.9:1 (180 mg/g of TDF vs. $200 \mathrm{mg} / \mathrm{g}$ of protein) and $0.7: 1$ (300 mg/g of TDF vs. $440 \mathrm{mg} / \mathrm{g}$ of protein), respectively [Kracht et al., 2004; Slominski et al., 2012]. To compare the tested levels with the naturally occurring ratios, the total non-protein content (i.e. $100 \%$ - protein \% based on DM) to protein content of mixed samples was considered. The TDF-RH trial had non-protein to protein mass ratios in mixed samples of 0.7:1 (low), 1:1 (medium), and 1.4:1 (high), whereas ratios in the TDF-RE trial were 0.8:1 (low), 1.1:1 (medium), and 1.6:1 (high). Thus, the gravimetric ratios of total protein to non-protein content applied in this study were similar or slightly higher than the relative proportions of protein to TDF found in the seed and meal. However, relatively high fibre contents were tested here compared to fibre-to-casein protein weight ratios ranging from $0.2: 1$ to 1:1 applied in earlier in vitro studies [Acton et al., 1982; Gagne \& Acton, 1983]. Therefore, this study served to both extend the upper range previously investigated for the potential effect of fibre on in vitro protein digestibility (IVPD) and to test the influence of using an alternative protein type derived from rapeseed. The IVPD assays offer several advantages compared to in vivo trials, such as the ability to examine relatively high dietary fibre contents and select specific E:S ratios.

\section{E:S ratios of samples and mixtures}

The IVPD procedure applied E:S ratios for pepsin and pancreatin that were initially optimized using bovine serum albumin to gain the highest possible protein digestibility within the $2 \mathrm{~h}$ total hydrolysis time (data not shown). The E:S ratios for the IVPD trials with the RP2 product, TDF
TABLE 2. Enzyme to substrate (E:S) ratios of samples and mixtures. ${ }^{1}$

\begin{tabular}{|c|c|c|c|c|}
\hline \multirow{2}{*}{$\begin{array}{l}\text { Samples } \\
\text { and mixtures }\end{array}$} & \multirow{2}{*}{$\begin{array}{l}\text { Substrate } \\
(\mathrm{mg})\end{array}$} & \multicolumn{3}{|c|}{$\mathrm{E}: \mathrm{S}$ ratios } \\
\hline & & $\begin{array}{c}\text { Pepsin } \\
\text { E:S }\end{array}$ & $\begin{array}{c}\text { Pancreatin } \\
\text { E:S }\end{array}$ & $\begin{array}{c}\text { Overall } \\
\text { E:S }\end{array}$ \\
\hline \multicolumn{5}{|c|}{ Samples } \\
\hline $\mathrm{RP} 2$ & 50.00 & 0.02 & 0.10 & 0.11 \\
\hline \multicolumn{5}{|c|}{ TDF-RH } \\
\hline Low & 2.27 & 0.43 & 2.10 & 2.53 \\
\hline Medium & 4.53 & 0.22 & 1.05 & 1.27 \\
\hline High & 9.06 & 0.11 & 0.53 & 0.63 \\
\hline \multicolumn{5}{|c|}{ TDF-RE } \\
\hline Low & 1.09 & 0.90 & 4.38 & 5.28 \\
\hline Medium & 2.17 & 0.45 & 2.19 & 2.64 \\
\hline High & 4.35 & 0.22 & 1.10 & 1.32 \\
\hline \multicolumn{5}{|c|}{ TDF-RH mixtures } \\
\hline Low & 52.27 & 0.02 & 0.09 & 0.11 \\
\hline Medium & 54.53 & 0.02 & 0.09 & 0.11 \\
\hline High & 59.06 & 0.02 & 0.08 & 0.10 \\
\hline \multicolumn{5}{|c|}{ TDF-RE mixtures } \\
\hline Low & 51.09 & 0.02 & 0.09 & 0.11 \\
\hline Medium & 52.17 & 0.02 & 0.09 & 0.11 \\
\hline High & 54.35 & 0.02 & 0.09 & 0.11 \\
\hline
\end{tabular}

${ }^{1} \mathrm{E}: \mathrm{S}$ ratios according to stage of digestion (pepsin or pancreatin digestion) were calculated as pepsin or pancreatin enzyme divided by total substrate protein (w:w). The overall E:S ratios were determined as total enzyme divided by total substrate protein (w:w). Abbreviations used: rapeseed protein concentrate 2 rich in napin proteins (RP2), total dietary fibre isolated from rapeseed hulls (TDF-RH), total dietary fibre isolated from rapeseed embryo fibres (TDF-RE). Low, Medium, and High refers to the inclusion levels of TDF fractions.

fractions, and sample mixtures according to phase of digestion are shown in Table 2. The E:S ratios for RP2 product tested alone were approximately $0.02: 1$ for the pepsin treatment, $0.10: 1$ for the pancreatin treatment, and $0.11: 1$ overall for the complete simulated in vitro gastrointestinal digestion.

The E:S ratios were considerably higher within the IVPD trials using TDF fractions alone (i.e. without the RP2 product) tested in equivalent amounts as in the mixed samples. The TDF-RH fraction alone had E:S ratios ranging from 0.11:1 to $0.43: 1$ (pepsin treatment), $0.53: 1$ to $2.10: 1$ (pancreatin treatment), and $0.63: 1$ to $2.53: 1$ (overall digestion). The corresponding E:S ratios for TDF-RE fraction alone were generally much higher than those of the TDF-RH fraction due to its lower protein content. The E:S ratios for the IVPD trials with the TDF fractions alone demonstrated that relatively high quantity of enzyme was present per total substrate protein. Consequently, the rate of proteolysis (i.e. IVPD), was expected to progressively increase along with the tested amount of TDF fraction unless product inhibition of IVPD occurred, TDF fractions contained substantial and variable quantities 
of IVPD resistant protein, and/or TDF fractions lowered the IVPD in a dose-dependent manner.

The E:S ratios of mixed samples were similar to those of the RP2 product alone given that RP2 constituted the majority of protein in all of the IVPD trials. The overall E:S ratios for all inclusion levels of TDF were kept nearly constant at $0.10-0.11: 1$. These conditions may not apply directly to the situation in humans, where there is continuous supply of new enzymes entering the gastrointestinal tract during digestion [Goodman, 2010]. The course of digestion in living organisms is a process in which the secretion and specific activity of digestive enzymes is adapted according to substrate intake and composition of the diet [Ren et al., 2012]. Therefore, the reduction in protein digestibility exerted by TDF reported in this study may not be directly comparable to in vivo conditions due to the modulated secretion and activity of proteolytic enzymes.

Besides the E:S ratios of mixed samples, it is important to assess if appropriate overall enzyme to TDF product mass ratios were tested in this study. High overall enzyme to TDF product mass ratios ( 0.07 to 0.16 ) were tested here compared to the levels (less than 0.05) used to investigate inhibition of trypsin activity with various types of purified DF [Hansen, 1986]. Hence, the effects of TDF on IVPD of rapeseed protein in our study were demonstrated at vastly lower relative amounts of DF to enzymes than tested previously. However, this comparison does not account for differences in DF compositions, the nature of proteolytic substrates, as well as the specific activity and origin of enzymes. Nevertheless, the mass ratios used in this study ensured an excess of overall enzymatic activity for digestion of rapeseed proteins without accounting for the inhibition exerted by TDF.

\section{IVPD of TDF fractions}

The TDF procedure was conducted on rapeseed hulls and rapeseed embryo fibres to degrade proteins associated with the fibre fractions. This ensured minimization of the effect of hydrolysable proteins within the fibre fractions on the IVPD of the primary protein source (i.e. the RP2 protein) within mixed samples. The residual protein content in TDF fractions may encompass resistant or partially degraded proteins originating from the starting fibre materials and/or enzymatic proteins added during the TDF isolation procedure. The overall protein digestibility after pepsin and pancreatin hydrolysis (IVPD PT \%) of TDF fractions alone (i.e. without RP2) as function of the overall E:S ratio is illustrated in Figure 2. The TDF fractions were tested in equivalent amounts as found in the mixed samples with RP2. The digestibility of residual protein in TDF fractions was linearly reduced in a dose-dependent manner as the included amounts were increased and the overall E:S ratios were lowered. The digestibility of protein in TDF-RH was significantly decreased from the low level $(32 \pm 2 \%)$ to the medium $(18.8 \pm 0.5 \% ; P<0.001)$ and high $(9.6 \pm 0.4 \% ; P<0.001)$ levels. Similarly, the digestibility of protein in TDF-RE was significantly reduced from the low level $(68 \pm 6 \%)$ to the medium $(36 \pm 4 \% ; P<0.001)$ and high $(18 \pm 2 \% ; P<0.001)$ levels.

The digestibility values for protein in the TDF fractions were all higher than the IVPD PT of the RP2 protein alone
(13.4 $\pm 0.6 \%)$, except for TDF-RH at high level $(9.6 \pm 0.4 \%)$, demonstrating that the residual proteins in the TDF fractions were highly digestible and would not per se lower the overall protein digestibility of RP2. In agreement with our findings, Bjergegaard et al. [1991b] found no correlation between the quantity of DF-associated nitrogen and the reduction of TD in the rat model. However, our results indicate that TDF fractions adversely affect the protein digestibility. This negative influence of DF on protein digestibility may be associated with a lowering of the proteolytic enzymatic activity, a reduction of the enzyme-substrate contact, or restriction of the access of enzymes into the fibre matrix [Shah et al., 1982; Dutta \& Hlasko, 1985; Hansen, 1986; Bjergegaard et al., 1991a]. Previous studies in vivo reported apparent ileal digestibility of nitrogen and crude protein in various wheat bran preparations ranging from about $57-63 \%$ in pigs and fecal nitrogen digestibility ranging from $63-73 \%$ in rats [Saunders \& Betschart, 1980; Schulze et al., 1994]. Furthermore, the apparent ileal digestibility of nitrogen was found to be increased with inclusion of higher levels of purified neutral detergent fibre to the pig diet [Schulze et al., 1994]. However, in the present study, digestibility of protein in TDF fractions without added RP2 was inversely related to the added amount of TDF. These discrepancies may be attributed to differences in model systems applied for determining protein digestibility and in the types of DF fractions investigated.

\section{Effect of TDF level and source on IVPD of RP2}

Table 3 presents the overall protein digestibility of RP2 in mixtures containing TDF-RH or TDF-RE. The digestibility of RP2 protein alone (control) without TDF added was $13.4 \pm 0.6 \%$, corresponding to an average peptide chain length of approximately 7.5 amino acids $(100 \% / 13.4 \%)$. The result for IVPD PT of RP2 protein in this study is generally of a much lower magnitude compared to previous in vitro lit-

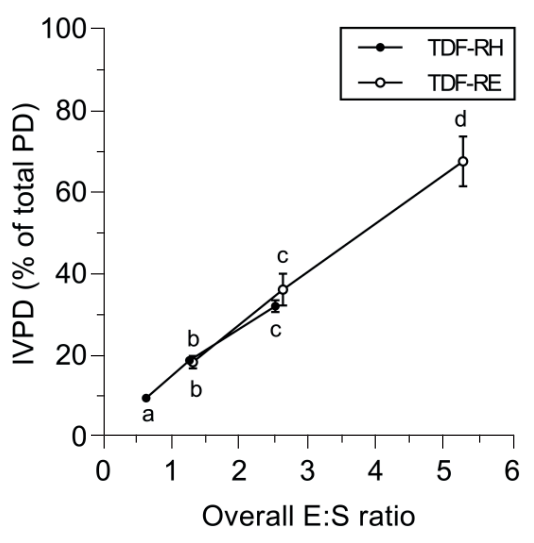

FIGURE 2. IVPD PT (\%) of TDF fractions without RP2 as a function of overall $\mathrm{E}: \mathrm{S}$ ratio (derived from Table 2).

Each point represents mean $\pm \mathrm{SD}$ of three determinations. Different letters indicate statistically significant differences $(P<0.05)$. Abbreviations used: total dietary fibre isolated from rapeseed hulls (TDF-RH), total dietary fibre isolated from rapeseed embryo fibres (TDF-RE), overall enzyme to substrate ratio (overall $\mathrm{E}: \mathrm{S}$ ratio), in vitro protein digestibility (IVPD), protein digestibility (PD). 
TABLE 3. IVPD PT (\%) of mixtures containing TDF-RH or TDF-RE.

\begin{tabular}{l|c|c|c}
\hline \multirow{2}{*}{$\begin{array}{l}\text { Samples } \\
\text { and mixtures }\end{array}$} & IVPD PT & \multicolumn{2}{|c}{ Reduction $^{2}$} \\
\cline { 2 - 4 } & $(\%)^{1}$ & $(\%)$ & $P$ \\
\hline \multicolumn{4}{c}{ Samples } \\
\hline RP2 $13.4 \pm 0.6$ & 8.9 & $<0.05$ \\
\hline LDF-RH mixtures & 14.2 & $<0.01$ \\
Medium & $12.2 \pm 0.3^{\mathrm{a}}$ & $<0.001$ \\
\hline High & $11.5 \pm 0.4^{\mathrm{a}}$ & 26.6 & $\mathrm{~ns}$ \\
\hline Low & $9.8 \pm 0.1^{\mathrm{b}}$ & $<0.05$ \\
Medium & TDF-RE mixtures & $<0.05$ \\
\hline High & $13.0 \pm 0.3^{\mathrm{x}}$ & 2.5 & 8.9 \\
\hline
\end{tabular}

${ }^{1}$ IVPD PT (\%) of RP2 protein in mixtures containing TDF-RH or TDFRE after short-term enzymatic hydrolysis. ${ }^{2}$ Reduction (\%) in IVPD PT of RP2 protein within sample mixtures relative to RP2 alone. Abbreviations used: rapeseed protein concentrate 2 rich in napin proteins (RP2), total dietary fibre isolated from rapeseed hulls (TDF-RH), total dietary fibre isolated from rapeseed embryo fibres (TDF-RE). Low, Medium, and High refers to the inclusion levels of TDF fractions.

erature data. A rapeseed protein concentrate predigested with pepsin for $30 \mathrm{~min}$ followed by pancreatin for $24 \mathrm{~h}$ showed an overall in vitro nitrogen digestibility of around $83 \%$ [Savoie et al., 1988]. The same authors demonstrated that a rapeseed protein concentrate predigested for $30 \mathrm{~min}$ with pepsin followed by $6 \mathrm{~h}$ partial pancreatin digestion led to in vitro nitrogen digestibility of about $40 \%$, which was similar to other protein sources including caseins, soya bean concentrate, peanut meal, dehulled field peas [Brulé \& Savoie, 1988]. Another study reported that commercial hexane-extracted rapeseed meal predigested for $3 \mathrm{~h}$ with pepsin followed by $24 \mathrm{~h}$ pancreatic digestion exhibited low in vitro digestibility assessed by degree of hydrolysis of around 19\%, whereas albumin, globulin, and glutelin protein fractions extracted from the meal showed higher DH values of approximately $67 \%$, $64 \%$, and 47\%, respectively [Ivanova et al., 2016]. Finally, the IVPD of RP2 tested in this study was recently found to be significantly increased when combined with selected bovine milk whey proteins such as beta-lactoglobulin [Joehnke et al., 2018]. In view of the broad variations in the experimental conditions (e.g. incubation times, enzyme levels, substrate types/levels) and quantification methods, we propose that IVPD results should be regarded in qualitative instead of quantitative terms.

TDF addition generally lowered the overall digestibility of RP2 protein compared to the RP2 control without fibre addition. Comparable results were obtained for overall protein digestibility (i.e. all proteins, not only RP2 protein) in the mixed samples (data not shown). However, the inverse association between TDF level added and digestibility of RP2 protein in mixed samples was largely dependent on the source of added TDF. The protein digestibility of RP2 was lowered upon inclusion of low and medium levels of TDF-RH, but these values were marginally insignificantly different from each other ( $P=0.05$; Table 3$)$. However, the RP2 protein digestibility was significantly reduced at the high inclusion level of TDF-RH compared to both the medium $(P<0.01)$ and low $(P<0.001)$ levels. Hence, sample mixtures containing TDF$\mathrm{RH}$ exhibited a distinct inverse dose-response relationship between the TDF level added and the overall protein digestibility of RP2. The digestibility of RP2 protein at the low, medium, and high inclusion levels of TDF-RH was reduced by $8.9 \%$ $(P<0.05), 14.2 \%(P<0.01)$, and $26.6 \%(P<0.001)$, respectively, relative to RP2 alone. The digestibility of RP2 in mixed samples containing TDF-RE included at low and medium level was significantly different $(P<0.05)$, whereas the high level was insignificantly different from the two other levels ( $P=0.08$ and $P=0.65$, respectively). There was no definite dose-response relationship between added level of TDF-RE and the reduction in digestibility of RP2 protein in sample mixtures, but a plateau for the negative impact of TDF-RE was observed above the $333 \mathrm{mg} / \mathrm{g}$ DM (medium) inclusion level. The decrease in digestibility of RP2 at the low level of TDF-RE was not significantly different $(P=0.65)$ from the control, while TDF-RE addition at the medium and high levels led to significant reductions in protein digestibility of $8.9 \%(P<0.05)$ and $7.3 \%(P<0.05)$, respectively, compared to RP2 alone.

TDF-induced reductions in protein digestibility demonstrated here were markedly higher than values presented in previous in vitro studies [Acton et al., 1982; Gagne \& Acton, 1983]. These authors reported a dose-dependent lowering of casein digestibility exerted by several purified DF types such as lignin and pectin ranging from about 2-5\% compared to the control. Such discrepancies are likely due to differences in the applied IVPD procedures, proteolytic substrates, and DF inclusion levels. The type and nature of DF also appears to be important for the effect on protein digestibility, since it may not be possible to reconstitute a functional fibre matrix after separation into individual fibre components. Finally, the E:S ratios used in this study may differ from the levels tested in the previous studies by Acton et al. [1982], which potentially contributes to higher reductions in the IVPD.

Similar to the present findings, a negative effect of rapeseed hulls on protein digestibility has been indirectly demonstrated in other studies, since dehulling of rapeseeds, press cakes, and meals led to an increased true ileal digestibility of protein in diets fed to pigs [Grala et al., 1998; Kracht et al., 2004]. Rapeseed hulls were found to increase the endogenous and dietary nitrogen in the ileal digesta of pigs primarily due to their high fibre content [Grala et al., 1998]. Bjergegaard et al. [1991a, b] showed that IDF isolated from rapeseed hulls and dehulled extracted rapeseed meal led to similar dose-dependent reductions in TD in rats ranging from about $5-10 \%$ and $3-9 \%$, respectively. In contrast, SDF isolated from traditional brown seeded rapeseed was found to exert significantly lower reductions of TD ranging from only $2-4 \%$ [Bjergegaard et al., 1991a, b]. Hence, these studies demonstrated that rapeseed hulls exerted a negative influence on protein digestibility, but also that DF found in other parts of the seed (e.g. the rapeseed embryo fibre fraction) is important. In agreement with this, a feeding study in piglets demonstrated that dehulled 
protein-rich rapeseed meal caused a dose-dependent decrease in TD ranging from about 3-4\%, which was strongly correlated with the dietary level of IDF [Danielsen et al., 1994]. Furthermore, a study of rodents fed a wheat starch-based diet containing various cultivars of double low unprocessed rapeseeds, demonstrated significant negative correlations between TD and intake levels of neutral detergent fibre, acid detergent fibre, hemicellulose, and TDF [Ochodzki et al., 1995].

The influence of indigestible protein and fibre-associated compounds within TDF fractions on the reduction of RP2 protein digestibility remains to be clarified. Saunders \& Betschart [1980] showed a positive correlation between the level of indigestible nitrogen in wheat milling fractions and the contents of crude fibre and dietary fibre in diets fed to rats. In addition, in the case of wheat bran, the average indigestible nitrogen was about $32 \%$ of the total nitrogen content. However, in the present study, the digestibility values of protein in TDF fractions alone (Figure 2) were nearly all higher than the RP2 control (Table 3). Consequently, the reduction in IVPD induced by TDF fractions does not appear to be linked to the presence of increased contents of proteins originating from the added fibre sources. The group of dietary fibre-associated compounds includes several indigestible components found in close connection with the non-starch polysaccharide (NSP) constituents, such as cell wall proteins (e.g. glycoproteins), phenolic compounds, oligosaccharides, and tannins [Bjergegaard et al., 1997]. The effect of fibre-associated compounds on protein digestibility may differ greatly according to processing procedures and composition of prepared products, and therefore the influence of such compounds requires further investigation. However, the method applied in this study may be used to examine the potential effects of individual fibre-associated compounds on the IVPD of rapeseed napin proteins.

For comparison of the two fibre sources, the overall protein digestibility values of RP2 in mixed samples containing TDF fractions were paired according to similarity in overall E:S ratio (Figure 3). This pairing of mixed samples was required to appropriately assess the effect of TDF sources on protein digestibility, independent of variations in the E:S ratios demonstrated to affect the protein digestibility (Figure 2). The digestibility of RP2 in mixed samples (i.e. TDF-RH Low vs. TDF-RE Medium) having similar overall E:S ratios was unaffected by the TDF source at the low to medium range inclusion levels $(P=1.00)$. In contrast, at the medium to high inclusion levels, the protein digestibility was significantly lower in the mixed samples containing TDF-RH compared to TDF-RE (TDF-RH Medium vs. TDF-RE High; $P<0.05$ ). These results generally demonstrate that TDF isolated from rapeseed hulls dose-dependently impairs the digestibility of rapeseed napin proteins, however, significant differences relative to TDF from rapeseed embryo fibres were only demonstrated at relatively high inclusion levels.

TDF fractions used in this study contain an unspecified combination of IDF and SDF. TDF purified from rapeseed hulls (TDF-RH) is primarily constituted of IDF and possess a high content of lignin [Bjergegaard et al., 1991a; Slominski et al., 2012], but the precise composition may vary according to different isolation procedures. Similarly, TDF-RE is expect- ed to have a high content of IDF relative to SDF, since a major proportion of SDF (e.g. pectins and $\beta$-glucans) is probably washed out during the preparation. However, the lignin content in TDF-RE is probably lower compared to TDF-RH [Slominski et al., 2012], which may explain the differential effects of the TDF fractions on protein digestibility. Lignin comprising $60 \mathrm{mg} / \mathrm{g}$ of a rat diet has been shown to elicit a similar decrease in true nitrogen digestibility as cellulose and pectin included at higher levels of $200 \mathrm{mg} / \mathrm{g}$ DM [Shah et al., 1982]. Furthermore, lignin was found to dose-dependently lower the IVPD of caseins to a comparable extent as pectin derived from apple [Acton et al., 1982; Gagne \& Acton, 1983]. Dietary inclusion of pectin in a corn starch-based diet at a level of $75 \mathrm{mg} / \mathrm{g}$ DM was shown to significantly depress the apparent ileal and fecal protein digestibility in pigs, owing to an increase in endogenous protein secretions and a decrease in the efficiency of protein digestion [Mosenthin et al., 1994]. Nevertheless, it was reported by the same authors that pectin did not affect the secretion or activity of pancreatic proteolytic enzymes in the pigs. Thus, several DF fractions and DF types present in a diet may be associated with a lowering of the protein digestibility. However, the relative influence of DF types within TDF on the reduction in digestibility of rapeseed napin proteins reported here remains to be clarified.

The mechanism(s) of action behind the differential effect of TDF fractions on IVPD of rapeseed napin proteins are difficult to establish based on data obtained in this study. DF may exert direct or indirect inhibitory effects on the activity of proteolytic enzymes through various mechanisms, thereby lowering the protein digestibility [Shah et al., 1982; Dutta \& Hlasko, 1985; Hansen, 1986; Bjergegaard et al., 1991a]. DF may also interact with proteins causing changes to their structural stability, functional properties, and digestibility patterns [Grundy et al., 2016; Zhang et al., 2017]. Napin proteins

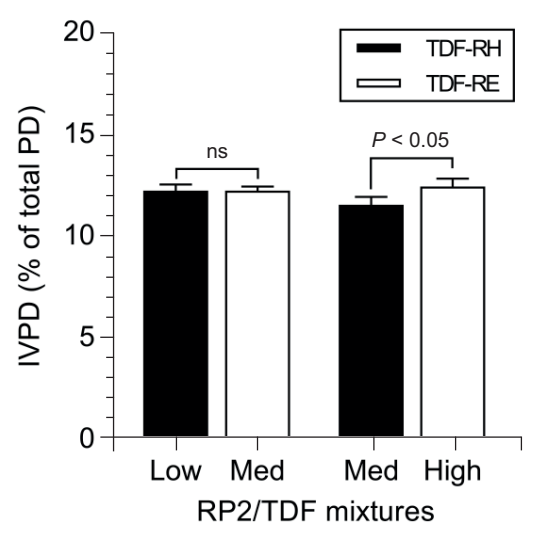

FIGURE 3. IVPD PT (\%) of RP2 protein in mixtures paired according to similarity in overall E:S mass ratio.

Each bar represents mean \pm SD of three determinations. Statistical significance was considered at $P<0.05$. ns; non-significant differences. Abbreviations used: total dietary fibre isolated from rapeseed hulls (TDF-RH), total dietary fibre isolated from rapeseed embryo fibres (TDF-RE), overall enzyme to substrate ratio (overall E:S ratio), in vitro protein digestibility (IVPD), protein digestibility (PD). Low, Medium (Med), and High refers to the inclusion levels of TDF fractions. 
are known from the literature to be capable of forming both soluble and insoluble complexes with anionic polysaccharides via electrostatic interactions, leading to alterations in their physicochemical properties such as isoelectric point and solubility [Stone et al., 2014]. Therefore, the results of this study are probably linked to a combination of various underlying mechanisms involving a complex interplay between the napin proteins, proteolytic enzymes, and the added TDF fractions.

Besides the effect of TDF fractions on IVPD, the digestibility of rapeseed proteins may be influenced by the presence of low molecular weight compounds such as glucosinolates and their degradation products, phenolic compounds, phytic acids, and trypsin inhibitors. These antinutritional compounds of rapeseed may interact with proteins and enzymes, thereby lowering their nutritional value [Khajali \& Slominski, 2012]. RP2 constitutes a highly purified product with a low trypsin inhibitor activity and high IVPD compared to other less refined napin-rich protein concentrates [Joehnke et al., 2018]. Thus, the trypsin inhibitor level of RP2 is negligible and unlikely to majorly affect the IVPD of napin proteins. However, RP2 also contains minor quantities of other antinutritional constituents like phenolic compounds and glucosinolate degradation products that may interfere with protein digestibility (data not shown). Further studies are required to clarify the relative and combined effects of the antinutritional compounds in rapeseed on the digestibility of napin proteins under both in vitro conditions and in vivo physiological settings.

Finally, the physiological relevance of the observed effect of TDF on IVPD is important to consider. TDF tested within this study can be found in animal feeds, and especially the rapeseed embryo fibres are expected to be important components of future foods containing increasing amounts of plant-based proteins. The applied proteolytic enzymes (pepsin and pancreatin) are found in man and all monogastric animal models used for studies of digestibility such as rats and pigs. The precise DF concentration in the intestinal/ duodenal juice after ingestion of a high fibre meal is difficult to predict, but has been proposed to be in the range of 5 to $15 \mathrm{~g} / \mathrm{L}$ [Dutta \& Hlasko, 1985]. This estimate is based on the assumption that a high fibre meal containing 25-30 g of DF is ingested along with $300 \mathrm{~mL}$ of liquid, subsequent to a 4-6 fold dilution due to salivary, gastric, and intestinal secretions [Dutta \& Hlasko, 1985]. TDF product concentrations used in the present study, corrected for protein content but not ash content, varied from about 2 to $6 \mathrm{~g} / \mathrm{L}$ during the pancreatic digestion phase. These concentrations of TDF are within the lower level expected after ingestion of a high fibre mixed meal in man and would likely correspond to the intake of a low to medium fibre content meal. However, it is difficult to relate the tested in vitro conditions to the digestive processes occurring in living organisms. Furthermore, IVPD studies are not directly applicable to results obtained under physiological conditions due to important limitations, such as the inability to account for temporal and spatial variations in gastric emptying and intestinal transit times, as well as the inability to dynamically adapt the E:S ratios according to the dietary composition. Therefore, the differential effect of TDF fractions on IVPD of rapeseed napin proteins demonstrated in this study must be supported and validated by in vivo trials in man.

\section{CONCLUSIONS}

The IVPD method applied in this study provides a simple and efficient model system for evaluating effects of different food components on protein digestibility. A direct inhibitory effect of TDF on protein digestibility of napin proteins was shown in mixtures reconstituted using rapeseed materials of identical origin (B. napus L., cv. Express). IVPD of rapeseed napin proteins within mixed samples was differentially affected by both the TDF inclusion level and fibre source. Rapeseed hull fibres led to significant reductions in protein digestibility at all inclusion levels, whilst the negative effect of rapeseed embryo fibres was solely exerted at the medium to high inclusion levels. The differential influence of TDF sources on protein digestibility was not statistically different at low to medium inclusion levels, whereas the hull fibres elicited a significantly lower protein digestibility at medium to high inclusion levels. Further studies are required to establish the effect of specific fibre types on the digestibility of rapeseed napin proteins and the overall protein digestibility in mixed food systems. The present study demonstrates that rapeseed hull fibres should be removed during processing by dehulling, whereas rapeseed embryo fibres may be present in high quantity without negatively affecting the digestibility of napin proteins. These results are important in the context of potential inclusion of water-soluble rapeseed protein concentrates or isolates in human nutrition, since naturally occurring TDF fractions applied in physiologically relevant levels were shown to differentially affect the IVPD of rapeseed napin proteins.

\section{ACKNOWLEDGEMENTS}

The authors gratefully acknowledge the HAPFAM project (Healthy and Affordable Proteins for the African Market) funded by The Danish Council for Strategic Research (20142018), in addition to industrial partners Arla Foods, TripleA $\mathrm{A} / \mathrm{S}$, and Fan Milk International A/S, for their financial support of this study.

\section{CONFLICT OF INTEREST}

The authors declare no conflicts of interest.

\section{REFERENCES}

1. Acton J.C., Breyer L., Satterlee L.D., Effect of dietary fiber constituents on the in vitro digestibility of casein. J. Food Sci., 1982, 47, 556-560.

2. Andersen K.E., Bagger C., Sørensen H., Sørensen J.C., A process for the manufacture of products from cruciferous crops. Denmark, Patent no. WO/2012/149941, 2012, Available from: [https://patents.google.com/patent/WO2012149941].

3. AOAC International, Official Method 985.29. Total dietary fiber in foods. 1985, in: Official Methods of Analysis of AOAC International, Gaithersburg, MD, USA. 
4. AOAC International, Official Method 950.46 (Modified). Moisture in meat. 2000, in: Official Methods of Analysis of AOAC International, Gaithersburg, MD, USA.

5. Asp N.G., Johansson C.G., Hallmer H., Siljeström M., Rapid enzymatic assay of insoluble and soluble dietary fiber. J. Agric. Food Chem., 1983, 31, 476-482.

6. Bjergegaard C., Eggum B.O., Jensen S.K., Sørensen H., Dietary fibres in oilseed rape: Physiological and antinutritional effects in rats of isolated IDF and SDF added to a standard diet. J. Anim. Physiol. Anim. Nutr., 1991a, 66, 69-79.

7. Bjergegaard C., Jensen S.K., Sørensen H., Dietary fibres in oilseed rape: Properties and effects on the digestibility of rapeseed meal. GCIRC Congr. Saskat. Can., 1991b, 2, 448-453.

8. Bjergegaard C., Sørensen H., Sørensen S., Dietary fibres and associated compounds in rape seed and biorefined rape seed products compared to DF in pea. J. Anim. Feed Sci., 1997, 6, 163-184.

9. Bos C., Airinei G., Mariotti F., Benamouzig R., Bérot S., Evrard J., Fénart E., Tomé D., Gaudichon C., The poor digestibility of rapeseed protein is balanced by its very high metabolic utilization in humans. J. Nutr., 2007, 137, 594-600.

10. Brulé D., Savoie L., In vitro digestibility of protein and amino acids in protein mixtures. J. Sci. Food Agric., 1988, 43, 361-372.

11. Campbell L., Rempel C.B., Wanasundara J.P.D., Canola/rapeseed protein: Future opportunities and directions - Workshop proceedings of IRC 2015. Plants, 2016, 5, art. no. 17.

12. Danielsen V., Eggum B.O., Jensen S.K., Sørensen H., Dehulled protein-rich rapeseed meal as a protein source for early weaned piglets. Anim. Feed Sci. Technol., 1994, 46, 239-250.

13. Dutta S.K., Hlasko J., Dietary fiber in pancreatic disease: effect of high-fiber diet on fat malabsorption in pancreatic insufficiency and in vitro study of the interaction of dietary fiber with pancreatic enzymes. Am. J. Clin. Nutr., 1985, 41, 517-525.

14. Fleddermann M., Fechner A., Rößler A., Bähr M., Pastor A., Liebert F., Jahreis G., Nutritional evaluation of rapeseed protein compared to soy protein for quality, plasma amino acids, and nitrogen balance - A randomized cross-over intervention study in humans. Clin. Nutr., 2013, 32, 519-526.

15. Gagne C.M., Acton J.C., Fiber constituents and fibrous food residue effects on the in vitro enzymatic digestion of protein. J. Food Sci., 1983, 48, 734-738.

16. Goodman B.E., Insights into digestion and absorption of major nutrients in humans. Adv. Physiol. Educ., 2010, 34, 44-53.

17. Grala W., Verstegen M.W., Jansman A.J., Huisman J., van Leeusen P., Ileal apparent protein and amino acid digestibilities and endogenous nitrogen losses in pigs fed soybean and rapeseed products. J. Anim. Sci., 1998, 76, 557-568.

18. Grundy M.M.-L., Edwards C.H., Mackie A.R., Gidley M.J., Butterworth P.J., Ellis P.R., Re-evaluation of the mechanisms of dietary fibre and implications for macronutrient bioaccessibility, digestion and postprandial metabolism. Br. J. Nutr., 2016, 116, 816-833.

19. Hansen W.E., Effect of dietary fiber on proteolytic pancreatic enzymes in vitro. Int. J. Pancreatol., 1986, 1, 341-351.

20. Ivanova P., Chalova V., Uzunova G., Koleva L., Manolov I., Biochemical characterization of industrially produced rapeseed meal as a protein source in food industry. Agric. Agric. Sci. Procedia, 2016, 10, 55-62.
21. Joehnke M.S., Rehder A., Sørensen S., Bjergegaard C., Sørensen J.C., Markedal K.E., In vitro digestibility of rapeseed and bovine whey protein mixtures. J. Agric. Food Chem., 2018, 66, 711-719.

22. Khajali F., Slominski B.A., Factors that affect the nutritive value of canola meal for poultry. Poult. Sci., 2012, 91, 2564-2575.

23. Kracht W., Dänicke S., Kluge H., Keller K., Matzke W., Hennig U., Schumann W., Effect of dehulling of rapeseed on feed value and nutrient digestibility of rape products in pigs. Arch. Anim. Nutr., 2004, 58, 389-404.

24. Mansour E.H., Dworschák E., Lugasi A., Gaál Ö., Barna É., Gergely A., Effect of processing on the antinutritive factors and nutritive value of rapeseed products. Food Chem., 1993, 47, 247-252.

25. Mosenthin R., Sauer W.C., Ahrens F., Dietary pectin's effect on ileal and fecal amino acid digestibility and exocrine pancreatic secretions in growing pigs. J. Nutr., 1994, 124, 1222-1229.

26. Ochodzki P., Rakowska M., Rek-Cieply B., Bjergegaard C., Sørensen $\mathrm{H}$., Studies on enzymatic fractionation, chemical composition and biological effects of dietary fibre in rape seed (Brassica napus L. ). 2. Influence of rape seed dietary fibre on digestibility of protein and organic matter using unprocessed and heated full fat rape seed and isolated dietary fibre fractions added to rat diets. J. Anim. Feed Sci., 1995, 4, 139-151.

27. Pasha I., Saeed F., Sultan M.T., Khan M.R., Rohi M., Recent developments in minimal processing: A tool to retain nutritional quality of food. Crit. Rev. Food Sci. Nutr., 2014, 54, 340-351.

28. Ren L.Q., Zhao F., Tan H.Z., Zhao J.T., Zhang J.Z., Zhang H.F., Effects of dietary protein source on the digestive enzyme activities and electrolyte composition in the small intestinal fluid of chickens. Poult. Sci., 2012, 91, 1641-1646.

29. Richter C.K., Skulas-Ray A.C., Champagne C.M., Kris-Etherton P.M., Plant protein and animal proteins: Do they differentially affect cardiovascular disease risk?. Adv. Nutr., 2015, 6, 712-728.

30. Saunders R.M., Betschart A.A., The significance of protein as a component of dietary fiber. Am. J. Clin. Nutr., 1980, 33, 960961.

31. Savoie L., Galibois I., Parent G., Charbonneau R., Sequential release of amino acids and peptides during in vitro digestion of casein and rapeseed proteins. Nutr. Res., 1988, 8, 1319-1326.

32. Schulze H., van Leeuwen P., Verstegen M.W., Huisman J., Souffrant W.B., Ahrens F., Effect of level of dietary neutral detergent fiber on ileal apparent digestibility and ileal nitrogen losses in pigs. J. Anim. Sci., 1994, 72, 2362-2368.

33. Shah N., Atallah M.T., Mahoney R.R., Pellett P.L., Effect of dietary fiber components on fecal nitrogen excretion and protein utilization in growing rats. J. Nutr., 1982, 112, 658-666.

34. Slominski B.A., Jia W., Rogiewicz A., Nyachoti C.M., Hickling D., Low-fiber canola. Part 1. Chemical and nutritive composition of the meal. J. Agric. Food Chem., 2012, 60, 12225-12230.

35. Stone A.K., Teymurova A., Dang Q., Abeysekara S., Karalash A., Nickerson M.T., Formation and functional attributes of electrostatic complexes involving napin protein isolate and anionic polysaccharides. Eur. Food Res. Technol., 2014, 238, 773-780.

36. Tan S.H., Mailer R.J., Blanchard C.L., Agboola S.O., Canola proteins for human consumption: Extraction, profile, and functional properties. J. Food Sci., 2011, 76, R16-R28. 
37. USDA FAS, Oilseeds: World Markets and Trade, 2018, Available from: [https://apps.fas.usda.gov/psdonline/circulars/oilseeds.pdf. Last accessed 04/06/2018].

38. Wanasundara J.P.D., Proteins of Brassicaceae oilseeds and their potential as a plant protein source. Crit. Rev. Food Sci. Nutr., 2011, 51, 635-677.
39. Zhang B., Liu G., Ying D., Sanguansri L., Augustin M.A., Effect of extrusion conditions on the physico-chemical properties and in vitro protein digestibility of canola meal. Food Res. Int., 2017, 100, 658-664.

Submitted: 6 April 2018. Revised: 23 May and 7 June 2018. Accepted: 28 June 2018. Published on-line: 17 August 2018. 